\title{
ANALISIS PENGANGKATAN CPU DI WM GAME CENTER DENGAN METODE RECOMMENDED WEIGHT LIMIT (RWL) DAN CHAFFIN ANDERSON
}

\author{
Muhammad Noviandy \\ Teknik Industri, Fakultas Sains dan Teknologi, Universitas Al-Azhar Indonesia \\ e-mail: muhammadnoviandy97@gmail.com
}

\begin{abstract}
ABSTRAK
Setiap pekerjaan memiliki beberapa resiko yang berkaitan dengan pengangkatan beban. Pekerjaan tersebut digolongkan ke dalam ilmu biomekanika. Biomekanika merupakan ilmu yang membahas aspek-aspek biomekanika dari gerakan-gerakan tubuh manusia. Pada penelitian kali ini, operator melakukan pengangkatan CPU seberat 6,7 kg. Diperlukan 2 metode untuk mengetahui apakah aktivitas tersebut berbahaya dan menimbulkan cidera pada bagian tubuh, yaitu Recommended Weight Limit (RWL) dan Chaffin Anderson. RWL merupakan rekomendasi batas beban yang dapat diangkat manusia tanpa menimbulkan cidera meskipun dilakukan secara repetitif dan dalam jangka waktu lama. Dari metode tersebut diperoleh hasil perhitungan RWL sebesar 46,37 dan Lifting Index sebesar 0,1. Hal ini berarti aktivitas pengangkatan CPU tidak berbahaya karena Lifting Index kurang dari 1. Sedangkan pada metode Chaffin Anderson yaitu menggambarkan tentang biomekanika statis pada tubuh ketika bekerja. Dari metode tersebut diperoleh F comp pada segmen L5/S1 sebesar 3826,85 N. Hal ini berarti aktivitas pengangkatan CPU tidak berbahaya karena F comp kurang dari 6500 $N$.
\end{abstract}

Kata kunci: Biomekanika, Chaffin Anderson, Ergonomi, RWL

\begin{abstract}
Every job has some risks associated with lifting weights. The work was classified into biomechanics. Biomechanics is the science that discusses the biomechanical aspects of human body movements. In this study, the operator removed the $6.7 \mathrm{~kg} C P U .2$ methods are needed to determine whether the activity is dangerous and cause injury to body parts, namely Recommended Weight Limit (RWL) and Chaffin Anderson. RWL is a recommended load limit that can be lifted by humans without causing injury even though it is done repetitively and for a long time. From these methods the RWL calculation results obtained were 46.37 and the Lifting Index was 0.1. This means that the activity of lifting the CPU is not dangerous because the Lifting Index is less than 1. Whereas in the Chaffin Anderson method which describes the static biomechanics in the body when working. From this method, the F comp in the L5 / S1 segment is $3826.85 \mathrm{~N}$. This means that the CPU removal activity is not dangerous because the F comp is less than $6500 \mathrm{~N}$.
\end{abstract}

Keywords: Biomechanics, Chaffin Anderson, Ergonomics, $R W L$

\section{PENDAHULUAN}

Pada era perkembangan saat ini yang semakin lama semakin canggih dengan didukungnya teknologi yang semakin maju, berbagai masalah dan pemecahannya dapat ditemukan dengan berbagai cara sehingga penyelesaian dari masalah tersebut dapat diselesaikan. Begitu pula dengan masalah-masalah yang timbul dalam aktivitas seperti pengangkatan dan pemindahan suatu barang atau yang lainnya. Dalam aktivitas pengangkatan dan pemindahan barang muncul berbagai keluhan yang menjadi masalah dalam aktivitas tersebut yaitu antara lain adalah Low Back Pain, Muscoloketal Disorders (MSDs), dan lain-lain. Masalah-masalah tersebut timbul karena faktor-faktor seperti postur kerja yang tidak alamiah, tenaga yang berlebihan, dan pengulangan kerja berkali-kali, serta lamanya waktu kerja. Pada persoalan tersebut dapat digunakan salah satu bidang dalam ilmu ergonomi yaitu biomekanika, sehingga dapat mengkaji permasalahan dalam aktivitas pengangkatan dan pemindahan CPU yang memiliki berat $6,7 \mathrm{~kg}$ dengan menggunakan perhitungan dan analisa biomekanika khususnya menggunakan metode Recommended Weight Limit (RWL) dan Chaffin Anderson sehingga tingkat resiko dari aktivitas tersebut 
dapat diketahui dan dapat ditentukan langkah langkah selanjutnya apakah metode yang digunakan dalam aktivitas pemindahan barang tersebut merupakan aktivitas yang dapat dipertahankan ataukah diganti agar tidak menimbulkan resiko-resiko cedera seperti low back pain, dan lain-lain. Tujuan dari penelitian ini adalah untuk mengetahui apakah aktivitas pemindahan CPU dilakukan oleh operator adalah aktivitas yang berbahaya atau tidak.

\section{METODE PENELITIAN Ergonomi}

Ergonomi merupakan disiplin ilmu yang menyangkut tentang keselamatan, kenyamanan, manusia di tempat kerja, di rumah, di sekolah dan tempat manapun yang menuntut manusia berinteraksi dengan lingkungan sekitar dengan tujuan utama untuk manusia dapat menyesuaikan dengan lingkungan sekitarnya [1].

\section{Biomekanika}

Biomekanika diklasifikasikan menjadi 2, yang pertama General Biomechanic merupakan bagian dari Biomekanika yang berbicara mengenai hukum-hukum dan konsepkonsep dasar yang mempengaruhi tubuh organik manusia baik dalam posisi diam maupun bergerak. Dibagi menjadi 2, yaitu: Biostatics adalah bagian dari biomekanika umum yang hanya menganalisis tubuh pada posisi diam atau bergerak pada garis lurus dengan kecepatan seragam (uniform) dan Biodinamics adalah bagian dari biomekanik umum yang berkaitan dengan gambaran gerakan-gerakantubuh tanpa mempertimbangkan gaya yang terjadi (kinematik) dan gerakan yang disebabkan gaya yang bekerja dalam tubuh (kinetik) [2]. Yang kedua, adalah Occupational Biomechanic, didefinisikan sebagai bagian dari biomekanik terapan yang mempelajari interaksi fisik antara pekerja dengan mesin, material dan peralatan dengan tujuan untuk meminimumkan keluhan pada sistem kerangka otot agar produktifitas kerja dapat meningkat. Setelah melihat klasifikasi diatas maka dalam penelitian kita ini dapat kita kategorikan dalam Biomekanik Occupational Biomechanic. Dalam biomekanik ini banyak melibatkan bagian tubuh yang saling berkolaborasi untuk menghasilkan gerak yang akan dilakukan oleh organ tubuh yakni kolaborasi Tulang, Connective Tissue atau jaringan penghubung, Otot (muscle) anaerobic dan aerobic. Perlu memperhatikan hal-hal seperti berikut untuk sedapat mungkin dihindari [3-7].

a. Beban otot statis (static muscle loads).

b. Oklusi (penyumbatan aliran darah) karena tekanan, misalnya tekanan segi meja pada popliteal (lipat lutut).

c. Bekerja dengan lengan berada di atas yang menyebabkan siku aliran darah bekerja berlawanan dengan arah gravitasi.

\section{Recommended Weight Limit (RWL)}

Menyatakan berat badan yang dapat diangkat oleh hampir semua pekerja sehat selama rentang waktu yang cukup lama, tanpa terjadinya peningkatan risiko sakit punggung yang berkaitan dengan pengangkatan. Persamaannya dapat dinyataan sebagai berikut:

$$
R W L=L C \times H M \times V M \times D M \times A M \times F M \times C M
$$

Dimana:

$$
\begin{aligned}
& \text { RWL }=\text { Recommended Weight Limit } \\
& \mathrm{LC}=\text { Load Constant } \\
& \mathrm{HM}=\text { Horizontal Multiplier } \\
& \mathrm{VM}=\text { Vertical Multiplier } \\
& \mathrm{DM}=\text { Distance Multiplier }
\end{aligned}
$$




$$
\begin{aligned}
& \mathrm{AM}=\text { Asymmetric Multiplier } \\
& \mathrm{FM}=\text { Frequency Multiplier } \\
& \mathrm{CM}=\text { Coupling Multiplier }
\end{aligned}
$$

\section{Lifting Index (LI)}

Proses metode RWL menghasilkan perhitungan Lifting Index untuk mengetahui indeks pengangkatan yang tidak mengandung resiko cidera tulang dengan persamaan:

$$
\mathrm{LI}=(\text { Load Weight/RWL) }
$$

Standar metode RWL adalah LI $<1$, maka aktivitas tersebut tidak mengandung resiko cidera tulang belakang sedangkan jika LI $>1$, maka aktivitas tersebut mengandung resiko cidera tulang belakang. Kelemahan metode ini adalah postur kerja tidak diperhatikan secara detail hanya gaya dan beban yang dianalisa, untuk penggunaan tenaga otot (statis/repetitif) dan postur leher belum dianalisa.

\section{Musculoskeletal Disorders (MSDs)}

Musculoskeletal Disorders (MSDs) atau invertebralis. Kerusakan pada otot dapat berupa ketegangan otot, inflamasi, dan degenerasi. Sedangkan gangguan otot rangka merupakan kerusakan pada otot, saraf, tendon, ligament, persendian, kartilago, dan discus kerusakan pada tulang dapat berupa memar, mikro faktur, patah, atau terpelintir. Aktivitas yang menjadi penyebab terjadinya MSDs yaitu penanganan bahan dengan punggung yang membungkuk atau memutar, membawa ke tempat yang jauh (aktivitas mendorong dan menarik), posisi kerja yang statik dengan punggung membungkuk atau terus menerus dan duduk atau berdiri tiba-tiba, mengemudikan kendaraan dalam waktu yang lama (getaran seluruh tubuh), pengulangan atau gerakan tiba-tiba meliputi memegang dengan atau tanpa kekuatan besar.

\section{Maximum Permissible Limit (MPL)}

MPL atau Maximum Permissible Limit merupakan batas besarnya gaya tekan pada segmen L5/S1 dari kegiatan pengangkatan dalam satuan Newton yang distandarkan oleh NIOSH (National Instiute of Occupational Safety and Health) tahun 1981.

Pada metode MPL, input berupa rentang postur (posisi aktivitas), ukuran beban dan ukuran manusia yang dievaluasi. Proses analisis dimulai dengan melakukan perhitungan gaya yang terjadi pada telapak tangan, lengan bawah, lengan atas, dan punggung. Output yang dihasilkan berupa gaya tekan/kompresi $(\mathrm{Fc})$ pada lumbar ke 5 sacrum pertama (L5S1). Proses metode MPL standart yang diberikan metode MPL adalah besar gaya tekan di bawah $6500 \mathrm{~N}$ pada L5/S1 sedangkan batasan gaya angkat normal (The Action Limit) sebesar 3500 pada L5/S1, sehingga didapat standar sebagai berikut:

1. Apabila Fc $<$ AL (Aman)

2. Apabila $\mathrm{AL}<\mathrm{Fc}<\mathrm{MPL}$ (Perlu hati-hati)

3. Apabila Fc $>$ MPL (Berbahaya)

\section{HASIL DAN PEMBAHASAN}

Dari penelitian kali ini operator melakukan aktivitas pemindahan CPU seberat 6.7 $\mathrm{kg}$, dari posisi awal ke posisi akhir. Gerakan saat akan mengangkat CPU dapat dilihat pada Gambar 1 berikut ini. 


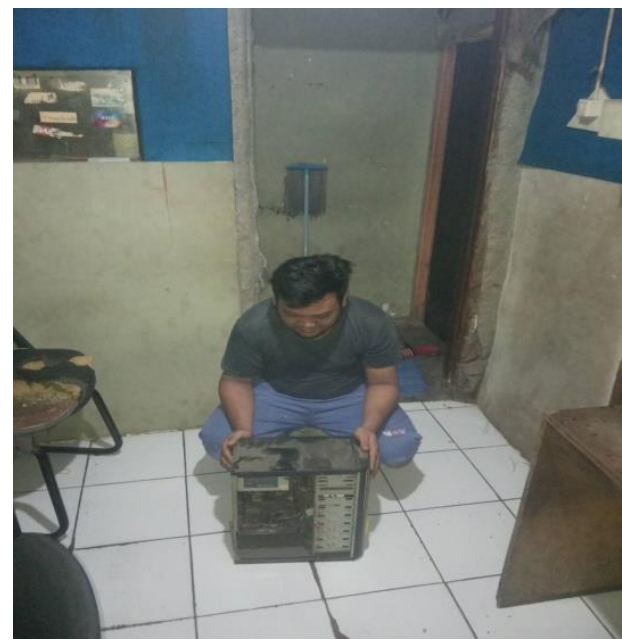

Gambar 1. Gerakan Saat Akan Mengangkat CPU

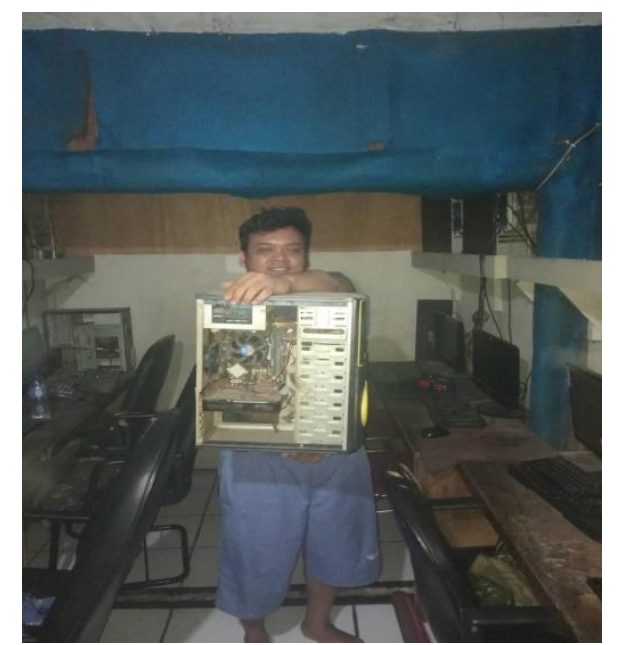

Gambar 2. Gerakan Saat Mengangkat CPU

Pada Gambar 1 dapat dilihat posisi operator saat sebelum mengangkat CPU dimana V = 0 karena posisi benda dan operator sejajar dengan tanah.Sedangkan pada gambar 2 dapat dilihat, operator sedang mengangkat CPU yang memiliki berat sebesar $6.7 \mathrm{~kg}$ sesuai dengan posisi yang dirasakan nyaman oleh operator.

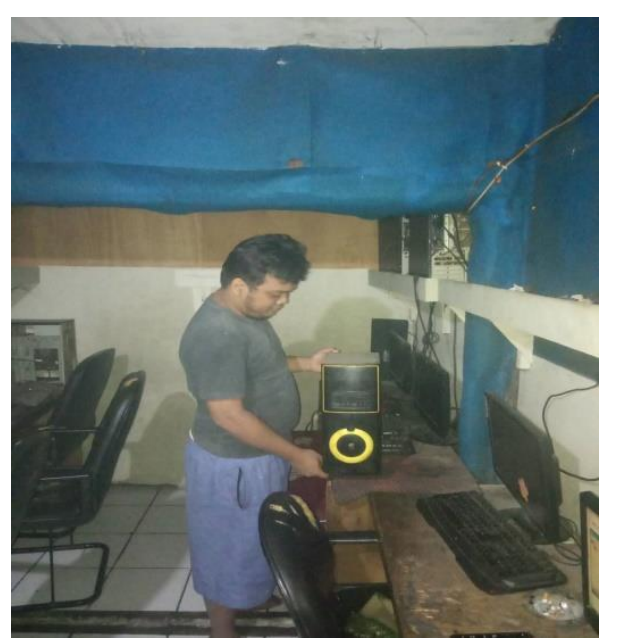

Gambar 3. Gerakan Saat Meletakkan CPU ke Atas Meja

Dan pada Gambar 3 dapat dilihat operator telah memindahkan CPU dari posisi awal yaitu berada di lantai yang sejajar dengan tanah ke posisi akhir dimana CPU tersebut diletakkan diatas meja setinggi $36.1 \mathrm{~cm}$. Setelah melakukan aktivitas didapatkan data dari pengukuran pada posisi yang dilakukan oleh operator ditunjukkan pada Tabel 1.

Tabel 1. Data Pengamatan Posisi Tubuh Pada Saat Aktivitas Pengangkatan CPU dengan Menggunakan Metode $R W L$

\begin{tabular}{ccc}
\hline Keterangan & Ukuran & Satuan \\
\hline L & 6.7 & Kg \\
H & 10.748 & Inch \\
V & 34.488 & Inch \\
D & 13.504 & Inch \\
A & 90 & Derajat \\
FM & 1 & \\
CM & 1 & \\
\hline
\end{tabular}


Pada Tabel 1 di atas, merupakan data pengukuran posisi tubuh saat operator melakukan aktivitas pengangkatan CPU dengan menggunakan metode $R W L$. Kemudian dilakukan pengukuran posisi tubuh saat operator melakukan aktivitas pengangkatan CPU dengan menggunakan Metode Chaffin Anderson. Data hasil pengamatan posisi tubuh pada saat aktivitas pengangkatan.

Tabel 2. Data Pengamatan Posisi Tubuh Pada Saat Aktivitas Pengangkatan CPU dengan Menggunakan Metode Chaffin Anderson

\begin{tabular}{ccc}
\hline Keterangan & Ukuran & Satuan \\
\hline $\mathrm{L}$ & 67 & Newton \\
$\mathrm{W}$ & 350 & Newton \\
$\mathrm{d}$ & 34.3 & $\mathrm{Cm}$ \\
1 & 29.7 & $\mathrm{Cm}$ \\
$\alpha$ & 45 & Derajat \\
$\theta$ & 90 & Derajat \\
$\mathrm{d}_{\text {abd }}$ & 11 & Cm \\
$\mathrm{d}_{\text {muscle }}$ & 5 & Cm \\
\hline
\end{tabular}

Pada Tabel 2, merupakan data hasil pengukuran posisi tubuh saat operator melakukan aktivitas pengangkatan CPU dengan menggunakan metode Chaffin Anderson.

\section{Hasil Analisis menggunakan Metode Recommended Weight Limit (RWL)}

Dengan menggunakan data yang telah diperoleh pada tabel 1 dengan mengamati dan melakukan pengukuran pada saat operator melakukan aktivitas mengangkat CPU yang akan dipindahkan dari posisi awal ke posisi akhir, yaitu diletakan diatas meja. Dari data yang telah didapat oleh operator, dapat dilakukan pengolahan data menggunakan metode Recommended Weight Limit (RWL). Berikut adalah hasil pengolahan data yang dilakukan operator:

Tabel 3. Tabel Pengolahan Data Dengan Menggunakan Metode Recommended Weight Limit (RWL)

\begin{tabular}{cc}
\hline Keterangan & Hasil \\
\hline RWL & 46.37 \\
Lifting Index & 0.1 \\
\hline
\end{tabular}

Dari pengolahan data yang dilakukan diatas didapatkan hasil untuk Recommended Weight Limit (RWL) sebesar 46.37 dan untuk Lifting Index sebesar 0.1. dapat dilihat dari hasil Lifting Index sebesar 0.1 yang dapat disimpulkan bahwa aktivitas yang dilakukan operator saat mengangkat CPU dikatagorikan tidak berbahaya untuk tubuh, karna hasil yang diperoleh $<1$. Resiko pada aktivitas tersebut terhadap tulang belakang adalah kecil dan tidak menimbulkan Musculoskeletal Disorders, Low Back Pain dan penyakit tulang belakang lainnya, karena operator melakukan aktivitas tersebut dengan posisi tubuh yang aman dan nyaman bagi operator.

\section{Hasil Analisis Menggunakan Metode Chaffin Anderson}

Dengan menggunakan data yang telah diperoleh pada Tabel 2 dengan mengamati dan melakukan pengukuran pada saat operator melakukan aktivitas mengangkat CPU yang akan dipindahkan dari posisi awal yang sejajar dengan tanah ke posisi akhir, yaitu di atas meja. Dari data yang telah diperoleh dapat dilakukan pengolahan data menggunakan metode Chaffin Anderson. Berikut adalah hasil pengolahan data yang dilakukan operator: 
Tabel 4. Tabel Pengolahan Data dengan Menggunakan Metode Chaffin Anderson

\begin{tabular}{cccc}
\hline Step & Keterangan & Hasil & Satuan \\
\hline 1 & M bw & 12635 & $\mathrm{~N} / \mathrm{cm}$ \\
2 & M load & 6009.9 & $\mathrm{~N} / \mathrm{cm}$ \\
3 & M L5/S1 & 186.449 & $\mathrm{~N} / \mathrm{m}$ \\
4 & $\mathrm{P}$ abd & 0.17 & $\mathrm{~N} / \mathrm{cm}^{2}$ \\
5 & $\mathrm{~F} \mathrm{abd}$ & 80.30 & $\mathrm{~N}$ \\
6 & F muscle & 3552.32 & $\mathrm{~N}$ \\
7 & F comp & 3826.85 & $\mathrm{~N}$ \\
\hline
\end{tabular}

Dari pengolahan data di atas, diperoleh gaya total (F comp) pada segmen L5/S1 sebesar 3826.85 N. Dari gaya yang dihasilkan yaitu $3826.85 \mathrm{~N}<6500 \mathrm{~N}$, maka dapat disimpulkan bahwa pekerjaan yang dilakukan masuk ke dalam katagori tidak berbahaya bagi tulang bagian L5/S1.

\section{KESIMPULAN}

Dari hasil pengumpulan data dan pengolahan data dengan perhitungan menggunakan 2 metode yaitu Recommended Weight Limit (RWL) dan Chaffin Anderson dapat disimpulkan pada perhitungan pertama menggunakan metode Recommended Weight Limit (RWL) diperoleh nilai RWL sebesar 46,37 dan nilai Lifting Index diperoleh sebesar 0.1 yang artinya aktivitas yang dilakukan tidak berbahaya $(<1)$. Dan pada perhitungan kedua menggunakan metode Chaffin Anderson diperoleh nilai F comp sebesar 3826,85 N yang nilainya lebih kecil dari $6500 \mathrm{~N}$. Maka pada kegiatan mengangkat CPU yang dipindahkan ke meja dapat dikatagorikan sebagai aktivitas yang tidak berbahaya dan tidak dapat menimbulkan cidera pada tulang belakang, tidak menimbulkan Musculoskeletal Disorders (MSDs), Low Back Pain, dan masih aman apabila kegiatan tersebut dilakukan secara berulang kali bagian segmen L5/S1.

\section{DAFTAR PUSTAKA}

[1].Norfiza, Z. Infi. (2011). Perancangan Alat Belajar dan Bermain Yang Ergonomis Di Taman Kanak- Kanak Islam Permata Selat Panjang. Jurnal Ilmiah Teknik Industri. [Online].(10)1. pp. 48-58. Available:http://journals.ums.ac.id/index.php/jiti/a rticle/view/1249/810.

[2]. Tayyari., 1997. Occupational Ergonomics, Principle and Application. London: Chapman \& Hall.

[3].Nurmianto, Eko. (1996). Ergonomi: Konsep Dasar dan Aplikasinya. Guna Widya. Surabaya.

[4].Ansar dan Sudaryanto. (2011). Biomekanik Osteokinematika dan Arthokinematika. Kementrian Kesehatan RI Politeknik Kesehatan Makassar. Makassar.

[5].Hidayat, Imam. (1999). Biomekanika. FPOK-IKIP Bandung. Bandung.

[6].Komari, Amat. (2010). Biomekanika Olahraga. FIK UNY. Yogyakarta.

[7].Ronald, Hamidie. (2003). Biomekanika Olahraga. Ikun. Jakarta. 